\title{
N-TERMINAL PRO-BRAIN NATRIURETIC PEPTIDE'S SERUM LEVEL IN SEVERE TRAUMATIC BRAIN INJURY
}

\author{
Cristina TASE GHINGULEAC ${ }^{1,2} \bowtie$, Bogdan GHINGULEAC ${ }^{1}$, Rodica TUDORAN $^{1,2}$, Ileana ION ${ }^{2}$ \\ ${ }^{1}$ County Clinical Emergency Hospital of Constanta, Romania \\ ${ }^{2}$ Faculty of Medicine, University „Ovidius“, Constanta, Romania
}

Received 5 Aug 2018, Accepted 1 Sept 2018

hitps://doi.org/10.31688/ABMU.2018.53.3.26

\begin{abstract}
Introduction. During the last decade, multiple studies tried to assess the correlation between brain hemorrhage and increased levels of Brain Natriuretic Peptide. These studies highlight the association between BNP plasma concentrations after traumatic brain injury and elevated intracranial pressure.
\end{abstract}

Case presentation. We present a case of a 40-year-old male, victim of a car accident, found in prehospital with 5 pts Glasgow Coma Scale (GCS) and with severe head, thorax and lower right limb traumatic lesions. After the first evaluation, it was necessary to protect the airways and to intubate the patient. The computed tomography $(\mathrm{CT})$ scan revealed multiple bone fractures of the skull with bilateral parietal epidural hematoma (30 mm thickness), pneumoencephaly, subarachnoid hemorrhage, concussion, multiple rib fractures with pulmonary contusion, double fractures of right fibula. Because the patient had severe thoracic and head trauma, we decided to complete the blood tests with N-terminal pro B-type Natriuretic Peptide (NT-proBNP) $(736 \mathrm{pg} / \mathrm{mL})$ and creatine kinase $(\mathrm{CK})$ (3853 U/L).

Conclusions. The association of polytrauma with increased levels of NT-proBNP present a continuous interest for researchers. An exact correlation between cerebral/cardiac trauma and this natriuretic peptide

\section{RÉsumÉ}

Le niveau dans le sérum de la peptide natriurétique cérébrale dans le cas de la lésion cérébrale traumatique sévère

Introduction. Au cours de la dernière décennie, de nombreuses études ont tenté d'évaluer la corrélation entre l'hémorragie cérébrale et l'augmentation des taux du Peptide Natriurétique Cérébral (BNP). Ces études mettent en évidence l'association entre les concentrations plasmatiques de BNP après une lésion cérébrale traumatique et une pression intracrânienne élevée.

Présentation du cas. Nous présentons un cas d'un homme de 40 ans, victime d'un accident de voiture, retrouvé avec un score de l'échelle de Glasgow (GCS) de 5 points et présentant des lésions traumatiques sévères de la tête, du thorax et du membre inférieur droit. Après la première évaluation, il était nécessaire de protéger les voies respiratoires et d'intuber le patient. La tomodensitométrie a révélé de multiples fractures du crâne avec hématome épidural pariétal bilatéral (épaisseur de $30 \mathrm{~mm}$ ), pneumoencéphalie, hémorragie sous-arachnoïdienne, commotion cérébrale, fractures multiples des côtes avec contusion pulmonaire, double fracture du péroné droit. Comme le patient présentait un traumatisme thoracique et un traumatisme crânien sévères, nous avons décidé de compléter les 
precursor has not been fully demonstrated yet, especially regarding the biological active form due to trauma. Further studies are currently performed to clarify the physiological role of this peptide, to confirm the correlation between its high levels and trauma, and to identify a specific role in the outcome of severe traumatic patients.

Keywords: brain natriuretic peptide, polytrauma, severe traumatic brain injury, emergency medicine, chest trauma.

\section{INTRODUCTION}

The risk of death in patients experiencing severe trauma is high, the majority of them die in prehospital, the rest of them has an increased death rate in the first 72 hours post admission ${ }^{1}$. The cases of head trauma account for over 1 million visits/year in both the USA and the UK and are responsible for two-thirds of all trauma deaths ${ }^{2}$. During the last decade, multiple studies tried to assess the correlation between brain hemorrhage and increased levels of Brain Natriuretic Peptide (BNP) ${ }^{2,3}$, taking into consideration the systemic effects of BNP, such as reducing the blood pressure and the plasma volume ${ }^{4}$. Also, this particular peptide has a regulatory role in the brain, water and electrolyte content, and it was found, in different experimental animal models, to reduce the intracranial pressure and brain edema ${ }^{4,5}$. These results highlight the association between BNP plasma concentrations after traumatic brain injury and elevated intracranial pressure $e^{2,4,6}$.

\section{Case presentation}

We present a case of a 40 year-old-male, victim of a car accident, with no pathological history, found in prehospital with 5 pts Glasgow Coma Scale (GCS) and with severe head, thorax and lower right limb traumatic lesions. After the first evaluation, it was necessary to protect the airways and to intubate the patient. In the Emergency Department (ED), the patient has been fully evaluated clinically, biologically and by imaging tests. With the primary and secondary evaluation, the patient had anisocoria (right eye tests sanguins avec la fraction $\mathrm{N}$-terminale du peptide natriurétique de type B (NT-proBNP) $(736 \mathrm{pg} / \mathrm{mL})$ et de la créatine kinase (3853 U/L).

Conclusions. L'association des polytraumatismes à des niveaux accrus de NT-proBNP présente un intérêt continu pour les chercheurs. Une corrélation exacte entre un traumatisme cérébral/ cardiaque et ce peptide précurseur natriurétique n'a pas encore été complètement démontrée, en particulier en ce qui concerne la forme biologique active due à un traumatisme. D'autres études sont actuellement effectuées pour clarifier le rôle physiologique de ce peptide, pour confirmer la corrélation entre ses niveaux élevés et les traumatismes, et pour identifier un rôle spécifique chez les patients traumatisés.

Mots-clés: peptide natriurétique cerebral, polytraumatisme, lésion cérébrale traumatique grave, médecine d'urgence, traumatisme thoracique.

mydriasis), reduced vesicular murmur on the right hemithorax, with $\mathrm{SpO}_{2}$ 100\% under mechanical ventilation, blood pressure $125 / 75 \mathrm{mmHg}$, and a heart rate of $87 \mathrm{bpm}$. The first set of blood tests showed leukocytosis $\left(14.6^{*} 10^{3} / \mu \mathrm{L}\right)$, normal hemoglobin level (12 g/dL), hepatic cytolysis syndrome (AST $500 \mathrm{U} / \mathrm{L}$, ALT $440 \mathrm{U} / \mathrm{L}$ ), normal coagulation tests. The computed tomography $(\mathrm{CT})$ scans revealed multiple bone fractures of the skull, with bilateral parietal epidural hematomas (30 $\mathrm{mm}$ thickness), pneumoencephaly (16/19 mm), subarachnoid hemorrhage, concussion, multiple rib fractures (III, IV, V, XI on the right side) with pulmonary contusion, a minimum left hemothorax and right comminuted fractures of both tibia and fibula (Figures 1-5). Because the patient had severe thoracic and head trauma, we decided to complete the blood tests with $\mathrm{N}$-terminal pro B-type Natriuretic Peptide (NT-proBNP) $(736 \mathrm{pg} / \mathrm{mL}$ ) and creatine kinase $(\mathrm{CK})(3853 \mathrm{U} / \mathrm{L})$.

Due to the severity of traumatic lesions, the patient undergone emergency surgery for the epidural hematomas. During surgery, the posterior $3^{\text {rd }}$ of the superior sagittal sinus was actively bleeding, and the hemorrhage was very difficult to manage, the blood pressure dropping to $40 / 20 \mathrm{mmHg}$. The hemoglobin level dropped to $6 \mathrm{~g} / \mathrm{dL}$ and the patient presented signs of hypovolemic shock. The patient was stabilized and admitted to the Intensive Care Unit. He was sedated and intubated, on ventilatory support, received blood transfusions and inotrope positive medication. The serum levels of NT-proBNP 24 hours after admission was $795 \mathrm{pg} / \mathrm{mL}$. The clinical and neurological status improved slowly, after 5 days 


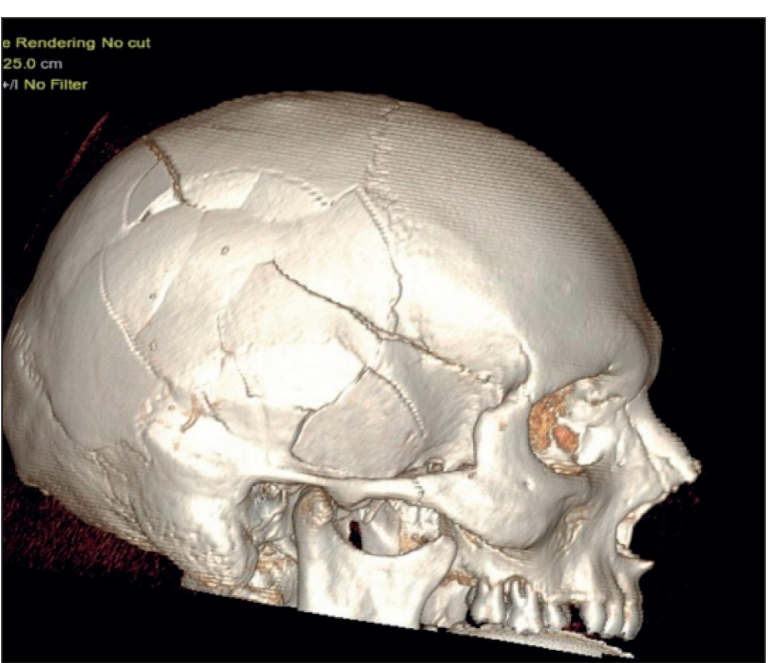

Figure 1. Preoperative 3D reconstruction showing bone fractures

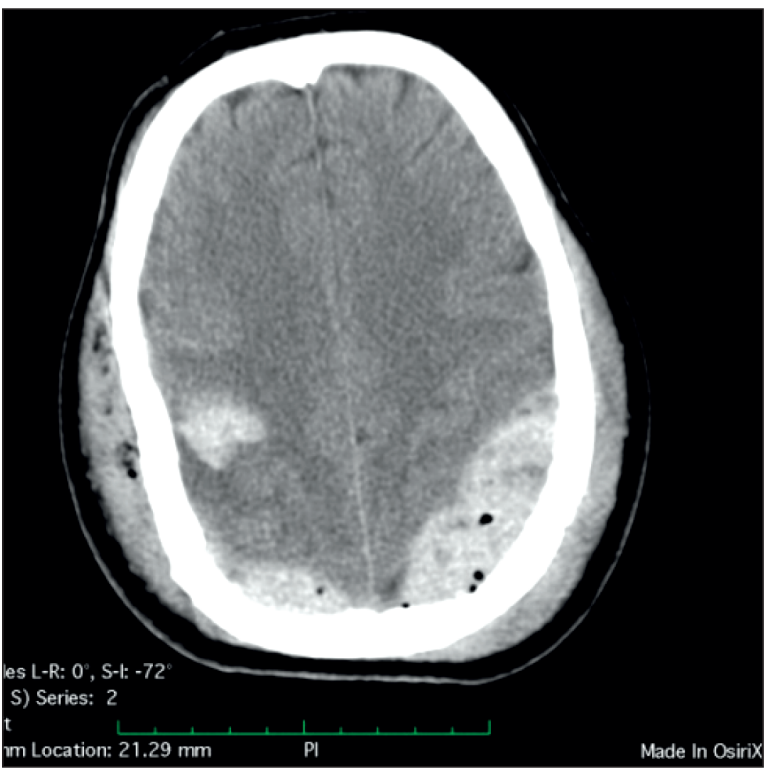

Figure 3. Preoperative CT scan showing bone fractures and the epidural hematomas.

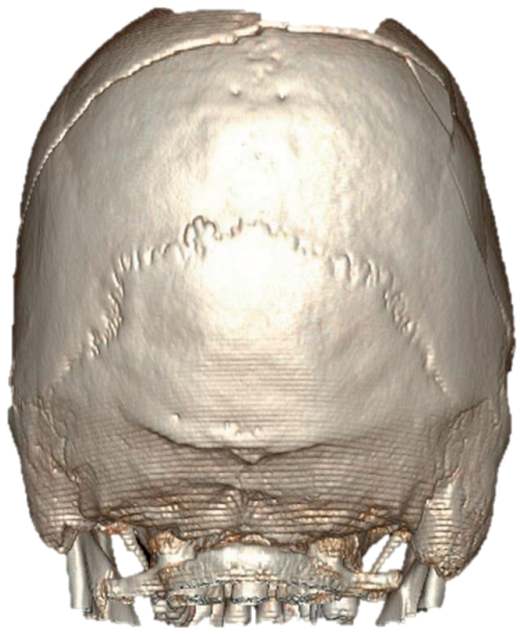

Figure 2. Preoperative 3D reconstruction showing bone fractures

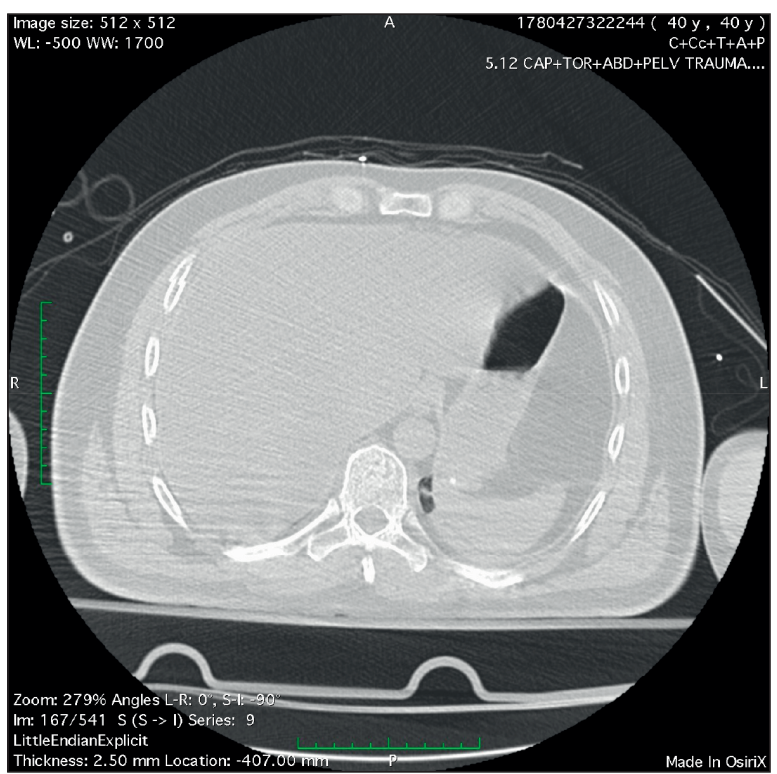

Figure 4. Preoperative thoracic CT scan showing rib fractures

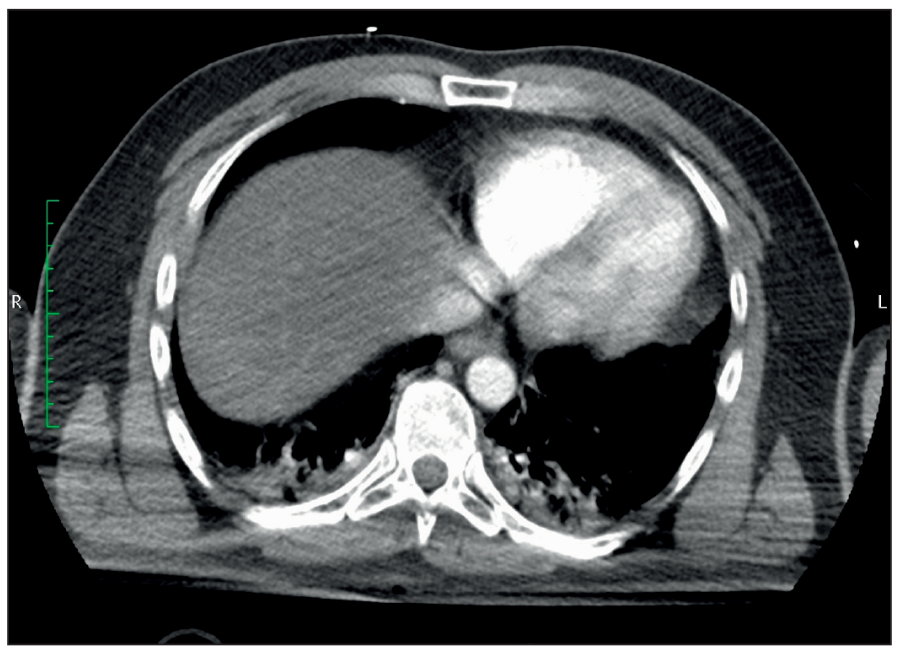

Figure 5. Preoperative thoracic CT scan showing pulmonary contusions 


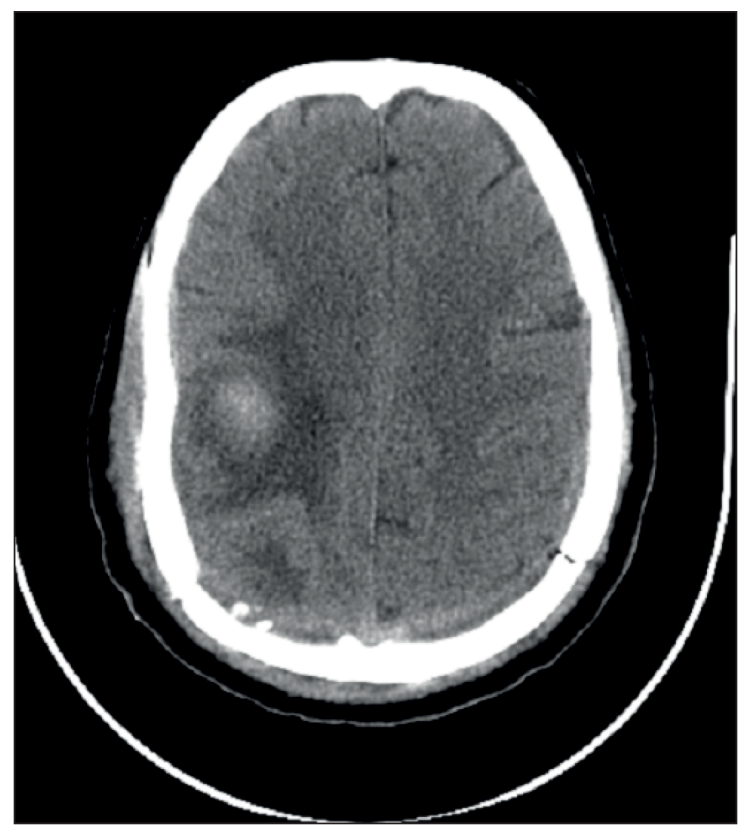

Figure 6. Postoperative CT scan two weeks after the injury

he regained consciousness and was extubated. The post-operative CT scan, 2 weeks after the traumatic event, showed a dimensional regression of the bilateral parietal epidural hematomas (6 $\mathrm{mm}$ thickness), resolution of the subarachnoid hemorrhage and the edema (Figure 6). At discharge, the level of NT-proBNP was $100 \mathrm{pg} / \mathrm{mL}$.

\section{Discussion}

The patient was a car accident victim, pedestrian, with frontal impact. His clinical status deteriorated rapidly and mechanical support for the airways was necessary. After secondary evaluation and support of the vital functions, in the hospital, blood tests were done, and CT scans were performed, highlighting the brain injury and multiple rib fractures. Post operatory, his clinical and biological status improved significantly.

The family of natriuretic peptides (NP) includes 3 well studied hormones: atrial natriuretic peptide (ANP), brain natriuretic peptide (BNP) and type C natriuretic peptide (CNP), all three being involved in maintaining the cardio-renal homeostasis. Several forms of proBNP, BNP and NT-proBNP, with different molecular masses have been identified ${ }^{3,5,6}$.

Cardiomyocytes react to the myocardial stretch caused by volume or pressure overload, activating the proper gene for BNP and creating an intracellular peptide preproBNP, made of 134 aminoacid residues. This propeptide is further cleaved and processed, releasing 2 types of peptides in the bloodstream: BNP, with 32 amino acids (biologically active), and NT-pro
BNP, with 76 amino acids ${ }^{7,8}$. NT-proBNP also has 7 glycosylation sites and has no biological activity until those sites are activated ${ }^{9}$. The half-life of NT-proBNP is longer (60-120 minutes), which explains the apparently higher concentration of NT-proBNP vs BNP in the blood $^{8}$

In the chronic heart failure, measuring BNP or NT-proBNP levels offers information regarding the risk of unfavorable evolution, with ventricular remodelation, malignant ventricular arrhythmias, hospitalization, necessity for cardiac transplant and death $^{10-13}$. In healthy adults, without heart failure, the serum levels of NT-proBNP have an upper limit of $125 \mathrm{pg} / \mathrm{mL}^{14}$. However, recent studies have shown a great correlation between NT-proBNP values and the outcome of polytraumatized patients, who present either cardiac trauma, cerebral trauma, or both. Even though a direct link was demonstrated only between active intracerebral hemorrhage and high NT-proBNP levels, underlining especially the role of the BNP in subarachnoidal aneurysmatic hemorrhage $(\mathrm{SAH})^{15}$, in patients with intracranial pressure, ongoing studies are still trying to correlate these high levels with other types of cardiac and cerebral trauma ${ }^{16-18}$.

The particularities of our case are: a patient with multiple severe traumatic lesions and high plasma levels of NT-proBNP, with a poor status on arrival and excellent evolution, due to an intense multidisciplinary medical management. After 2 weeks of hospitalization, the patient was stable, with almost a complete recovery of his neurological function. The adequate management of this particular type of case requires special attention, starting with the first 
evaluation of the patient, the biological and imaging tests, and the proper treatment. The NT-proBNP values may be useful in estimating the outcome of these patients.

\section{Conclusions}

The association of polytrauma with increased levels of NT-proBNP present a continuous interest for researchers. An exact correlation between cerebral/ cardiac trauma and this natriuretic peptide precursor has not been fully demonstrated yet, especially regarding the biological active form due to trauma. Further studies are currently performed to clarify the physiological role of this peptide, to confirm the correlation between its high levels and trauma, and to identify a specific role in the outcome of severe traumatic patients.

\section{Compliance with Ethics Requirements:}

„The authors declare no conflict of interest regarding this article"

„The authors declare that all the procedures and experiments of this study respect the ethical standards in the Helsinki Declaration of 1975, as revised in 2008(5), as well as the national law. Informed consent was obtained from the patient included in the study"

"No funding for this study"

\section{References}

1. Masella CA, Pinho VF, Costa Passos AD, Spencer Netto FA, Rizzoli S, Scarpelini S. Temporal distribution of trauma deaths: quality of trauma care in a developing country. $J$ Trauma 2008;65(3):653-8

2. AzizkhaniR, Keshavarz E. Investigation of changes in brain natriuretic peptide serum levels and its diagnostic value in patients with mild and moderate head trauma, in patients referred to emergency department of Alzahra Hospital, Isfahan, 2013-2014. Adv Biomed Res 2016; 5:191.

3. Levin ER, Gardner DG, Samson WK. Natriuretic peptides. N Engl J Med 1998;339:321-8.
4. Minamikawa J, Kikuchi H, Ishikawa M, Yamamura K, Kanashiro M. The effects of atrial natriuretic peptide on brain edema, intracranial pressure and cerebral energy metabolism in rat congenital hydrocephalus. Acta Neurochir Suppl (Wien) 1994;60:104-6.

5. Wu X, Sha H, Sun Y, et al. N-terminal pro-B-type natriuretic peptide in patients with isolated traumatic brain injury: a prospective cohort study. J Trauma 2011;71(4):820-5; discussion 825 .

6. Nakao K, Kanagawa K. The natriuretic peptide family $1^{\text {st }}$ Edition. Tokyo Kodansha Scientific 1995.

7. Schellenberger U, O'Rear J, Guzzetta A, Jue RA, Protter AA, Pollitt NS. The precursor to B-type natriuretic peptide is an O-linked glycoprotein. Arch Biochem Biophys 2006;451:160-166.

8. Semenov AG, Postnikov AB, Tamm NN, et al. Processing of proBNP is suppressed by $\mathrm{O}$-glycosylation in the region close to the cleavage site. Clin Chem 2009;55(3):489-98.

9. Seferian KR, Tamm NN, Semenov AG, et al. The brain natriuretic peptide (BNP) precursor is the major immunoreactive form of BNP in patients with heart failure. Clin Chem 2007;53(5):866-873.

10. Bodean $\mathrm{O}$, Bratu $\mathrm{O}$, Munteanu $\mathrm{O}$, et al. Iatrogenic injury of the low urinary tract in women undergoing pelvic surgical interventions. Arch Balk Med Union 2018;53(2):281-284.

11. Diaconu C, Bartos D. Biomarkers: a step forward in heart failure diagnosis and risk stratification. Medicina Internă 2012;IX(1):35-39.

12. Draghici T, Negreanu L, Bratu OG, et al. Liver abnormalities in patients with heart failure. Arch Balk Med Union 2018;53(1):76-81.

13. Horodinschi R, Ionescu C, Belciu D, Diaconu C. How can anemia affect the heart? Arch Balk Med Union 2017;52(2):214-218.

14. Ponikowski P, Voors AA, Anker SD, et al. 2016 ESC Guidelines for the diagnosis and treatment of acute and chronic heart failure. Eur Heart J 2016, 37(27):2129-2200.

15. Kirchhoff C, Stegmaier J, Bogner V, et al. Intrathecal and systemic concentration of NT-proBNP in patients with severe traumatic brain injury. J Neurotrauma. 2006;23(6):943-9.

16. Flynn TG, de Bold ML, de Bold AJ. The amino acid sequence of anatrial peptide with potent diuretic and natriuretic properties. Biochem Biophys Res Commun 1983; 117:859-865.

17. Liener UC, Rapp U, Lampl L, et al. Incidence of severe injuries. Results of a population - based analysis. Unfallchirurg 2004;107:483-490.

18. Kuhn M. Molecular physiology of natriuretic peptide signaling. Basic Res Cardiol 2004;99:76-82. 